\title{
Work Related Stress among Staff Nurses at a Private Hospital in Singapore
}

\section{Nancy Justine, Fenny Justine, Esther Declara Gani, Geraldine Stephen, Kasmah Yamin Beatrice Hailis Sebastian, Tukimin Sansuito, Regidor-111 Dioso*}

Lecturer, Faculty of Nursing, Lincoln University College, Malaysia. duke@lincoln.edu.my

*Corresponding Author: Regidor-111 Dioso, Lecturer, Faculty of Nursing, Lincoln University College, Malaysia.

\section{Abstract}

This study hoped to determine work related stress among nurses in a private hospital in Singapore. A quantitative descriptive study design specifically a cross sectional was used. Convenience sampling technique selected 60 nurse respondents to answer the self administered questionnaire. There was a probability of work related stress ( $p=0.0002)$ as compared to that of without $(p=0.04)$. In Singapore, some point of stress was required for success.

Keywords: cross-sectional, nurses, Singapore, stress

\section{INTRODUCTION}

According to Garrosa et al (2010), a healthy workplace is one in which workers and managers collaborate to use a continual enhancement process to protect and promote the health, safety and well-being of all workers and the sustainability of the workplace. Stress nowadays affects nearly all in some way or the other. Minter (1999) expresses stress as "harmful physical and emotional reactions that happen when necessities of a profession do not match the competences, assets or desires of the worker." Schuler (1982) is of the view that stress is "alleged dynamic state concerning uncertainty about something significant".

\section{Problem Statement}

Nurses suffer from high levels of work-related stress. Stress also has been cited as one reason for turnover (McVicar, 2003), resulting in negative effects on services and quality and continuity of care (Department of Health and Children, 2002).

\section{Significance}

The researchers believed that this study would be significant to help nurses in avoiding stressor during working in a hospital setting. Stress is a part of everyday life for health professionals such as nurse's physicians and hospital administrators (Chayu \&
Kreitler, 2011). Review of literature has reviled that there are various factors responsible for stress among nurses working in hospital areas.

\section{Research Objective}

On account of these issues, it is hoped to determine work related stress among nurses in a private hospital in Singapore.

\section{Operational Definition}

Occupational Stress-refers to job strain experienced by employees due todifferent unfavorable factors in the workplace

Pre-Natal-pregnant woman are those within 37 weeks without any complication experiencing signs of labor.

Post-Natal-Mothers after delivering their baby(s) handled by staff nurses without any complication.

\section{MethodologY}

This section deals with the methodology under the following headings: research design, sample size and sampling techniques, description of the questionnaire, and procedure of data collection and plan for data analysis. 
Work Related Stress among Staff Nurses at a Private Hospital in Singapore

\section{Research Design}

In order to meet the objectives this study used a quantitative descriptive study design. Specifically a cross sectional study type was used.

\section{Sampling Technique}

Convenience sampling technique was used. The 60 nurse respondents were employed. The list assisted in determining the size of the sample is highlighted in table 1.

\begin{tabular}{|l|l|l|}
\hline Table 1. Sample Size \\
\hline Sections & $\begin{array}{l}\text { Registered } \\
\text { Nurse- } \\
\text { Midwives }\end{array}$ & $\begin{array}{l}\text { Registered } \\
\text { General } \\
\text { Nurses }\end{array}$ \\
\hline Pre Natal & 3 & 27 \\
\hline Post Natal & 2 & 28 \\
\hline
\end{tabular}

All the nurses considered were registered having $n=55$ general nurses and $\mathrm{n}=5$ nurse-midwives, working fulltime for a period of more than two years. We conveniently selected the nurse respondents based on their availability.

\section{Questionnaire as Instrument}

The International Stress Management Association (ISMA) produced by the Health and Safety Executive questionnaire was used as questionnaire to collect data from the nurses. The ISMA questionnaire consisted of 25 questions overall (appendix 1) and the nurse respondents need to choose either yes or no and tick the answers consequently. Only 15 minutes were provided to answer the questionnaire which focused on demographic data information, and work stress. The questionnaires were distributed in the pre-natal and post-natal ward at Thomson Medical Centre, Singapore. A pilot study was also conducted to ensure validity and reliability of the self-administered questionnaire.

\section{Ethical Consideration}

An ethical clearance was obtained from Lincoln University College, Malaysia, Research and Ethics Committee. Permission was also sought from the Thomson Medical Centre, Singapore. Consents were obtained from the respondents who took part in the study. Respondents were given the chance to withdraw at any time without questions asked (Polit \& Beck, 2010).

\section{Data Analysis}

Data were coded and entered into SPSS software version 21. Descriptive statistics (mean, standard deviation and probability) were used. Analysis of quantitative data included frequencies to describe the sample characteristics (Polit \& Beck, 2010).

\section{RESULTS AND FINDINGS}

A total of 60 respondents answered the questionnaire, generating a response rate of $100 \%$. The demography highlights the particularly the age, race, and clinical experiences affecting the variables. Table 2 shows the demographic profile of the respondents.

\begin{tabular}{|c|c|c|c|}
\hline & & $\mathrm{n}$ & $\%$ \\
\hline \multirow{3}{*}{ Age } & 20 - 40 years & 33 & 55.0 \\
\hline & $41-50$ years & 23 & 38.3 \\
\hline & $>50$ years & 4 & 6.7 \\
\hline \multirow{4}{*}{ Race } & Chinese & 17 & 28.3 \\
\hline & Indian & 14 & 23.3 \\
\hline & Malay & 13 & 21.7 \\
\hline & Others & 16 & 26.7 \\
\hline \multirow{4}{*}{$\begin{array}{l}\text { Clinical } \\
\text { experience }\end{array}$} & $<5$ years & 18 & 30.0 \\
\hline & $5-10$ years & 21 & 35.0 \\
\hline & $11-15$ years & 7 & 11.7 \\
\hline & >15years & 14 & 23.3 \\
\hline
\end{tabular}

On table 3 , there is a narrowed mean and standard deviation on both yes $(35 \pm 10.4)$ and no $(25 \pm 10.3)$ answers to determine work related stress. There is a probability of work related stress $(\mathrm{p}=0.0002)$ as compared to that of without $(\mathrm{p}=0.04)$. However, it is also probable that nurses did not experience much work related stress affected by age, race and clinical experiences.

\begin{tabular}{|l|l|l|l|l|}
\hline \multicolumn{5}{|l|}{$\begin{array}{l}\text { Table 3. Work related stress summary of the ISMA } \\
\text { survey questionnaire }\end{array}$} \\
\hline $\begin{array}{l}\text { Work related } \\
\text { stress }\end{array}$ & $\mathrm{n}$ & $\%$ & Mean & Probability \\
\hline Yes & 33 & 55 & $35 \pm 10.4$ & 0.0002 \\
\hline No & 27 & 45 & $25 \pm 10.3$ & 0.04 \\
\hline
\end{tabular}

It is therefore determined, that the study on occupational stress is a noteworthy topic in the nursing field. Occupational stress is recognized worldwide as a major challenge to workers' health and their organizations (Salilih \& Abajobir, 2014). 


\section{DISCUSSIONS}

The generalization of findings from this research may only be limited to the specific hospital where this study was conducted. Furthermore, there are various aspects of this research that were beyond the control in the research process because of limited exploration. The lived experiences were not reported thereby narrowing the results to mathematical expressions.

The respondents were required to recall all incidents of work related stress. It is therefore highly possible that the participants may have forgotten all the incidents. These were few challenges especially in reporting the findings. It was also emphasized to respondents to answer the questions truthfully to avoid biases. That is why it is important to discuss the factors affecting work related stress among the respondents that may have confounded the variables and in some point led to a bias result.

\section{Demography as a Factor}

There are more respondents who are at the age bracket of 20-40 years old $(n=33)$ as compared to that of the 41-50 years old $(n=23)$. The younger respondents have more tolerance on work related stress as compared with the older nurses (Salilih \& Abajobir, 2014). That is why most of the older respondents agreed that they have experienced work related stress.

Similarly, age is also reflective of the years of clinical experience. However, having more respondents who worked 5-10 years $(n=21)$ in between younger and older age is difficult to determine. Less than 5 years in working experience $(n=18)$ are those who have responded of experiencing lesser work related stress. The respondents who are older ( $>50$ years old) and have been in service for more than 15 years $(n=14)$ had more experiences on work related stress.

With regards to race, Chinese respondents $(n=17)$ had less experiences in work related stress as compared with the Indians $(n=14)$, and Malays $(n=13)$. The other races $(n=60)$ in this hospital such as Filipinos, Nepalese, Africans, and Indonesian nurses have less experiences in work related stress.

\section{Other Factor}

The study revealed that the main causes of occupational stress among nurses that are not enough hours in the day to do all the things (83.3\%), and the less causes of occupational stress among nurses are greater dependency on alcohol, caffeine, nicotine or medicines to keep them awake (13.3\%). The causes of occupational stress among nurses call for urgent need to design interventions which can easier make the work environment conducive.

The environment which individuals work determine the level of satisfaction with work performed and can also contribute to stress. The results for environment factor revealed that the main causes of occupational stress among nurses are pressured work on long hours (75\%).

A day-to-day encounter at work is also considered as a factor (Salilih \& Abajobir, 2014). That is why Singapore hospitals have already come up with interventions to reduce the problems of improving relationships among members of staff and salary increments. Particularly in this hospital, it is still important to have a healthy mind and body to avoid stress.

Stress affects the employer and employees alike (Department of Health and Children, 2002). Therefore, there is a need to prevent stress in the workplace to improve the quality of lives and contribute positively towards improved productivity of the organizations. On the one hand, the understanding of the relationship between stress and the workplace is still a challenge, and thus it is important to acknowledge that work can cause stress (Garrosa et al, 2010).

This study determined that in Singapore, some point of stress is required for success. However, high levels of stress follows several implications including physical and psychological diseases such as anxiety, depression, sleep disorders, restlessness, irritability, dementia, abnormal fatigue, reduced resistance and susceptibility to frequent infections, headache, reduced concentration, memory disorders, and decreased levels of problem-solving abilities (Craine et al., 2010). By turning toxic work environments into healthy workplaces, researchers and nurse leaders suppose that improvements can be realized in recruitment and retention of nurses, job satisfaction for all health care staff, and patient outcomes particularly those related to patient safety (Costa \& 
Work Related Stress among Staff Nurses at a Private Hospital in Singapore

McCrae, 1990). Nurses find themselves particularly at risk because of their working environment. According to Salilih \& Abajobir (2014) support groups as well as development consultation with nurse managers have also been effective in resolving problems across interdisciplinary staff teams.

\section{CONCLUSION AND RECOMMENDATION}

\section{Conclusion}

There is a probability of work related stress $(\mathrm{p}=0.0002)$ as compared to that of without ( $\mathrm{p}=0.04)$. In Singapore, some point of stress is required for success.

\section{Recommendations}

The following recommendations are specifically appropriate in Singapore setting:

Introduction of Interventions in the Workplace to Address Occupational Stress among the Nurses: An urgent need to come up with interventions that are specifically designed to address stress issues that are experiences by nurses. The interventions should be relaxation techniques, ergonomics and equipment management and improved ventilation that can reduce stress in the workplace (Costa \& McCrae, 1990). Sending members of staff on retreats, outings, and in-house ward parties or events and create active wellness programs. Improve work environment by also addressing work conditions such as working relationships, addressing staff welfare (Garrosa et al, 2010).

Reducing the Extent of Overload: There is a need to reduce work-overload by ensuring that there is adequate manpower and also by ensuring nurses ratio vs. patients is adequately addressed (Pillay, 2009). Volunteers such as student nurses may be helpful in reducing workload of employed registered nurses.

Staff Motivation: There is need to motivate staff in order to increase level of job satisfaction. Staff welfare such as recognition, promotion, and salary increments needs to be considered as motivating factors (Salilih \& Abajobir, 2014). This calls for managers to take interest in such recommendations.

\section{REFERENCES}

[1] Chayu, T. \& Kreitler, S. (2011). Burnout in nephrology nurses in Israel. Nephrol. Nurs. J. 2011, 38, 65-78.
[2] Costa, P., \& McCrae, R. (1990). Controlling neuroticism in the measurement of stress. Stress Medicine , 5, 237-241.

[3] Craine J. M, Elmore A. J, Olson K, Tolleson D. Climate change and cattle nutritional stress. Global Change Biology. 2010;16(10):2901-11. http://dx.doi. org /10.1111/j.1365 -2486.2009.02060.x

[4] Department of Health and Children (2002). The nursing and midwifery resource, final report of the steering group: Towards workforce planning. Dublin: Author. Available from http://www.dohc. ie/publications/towards_workforce_planning. html (Accessed September 16, 2012

[5] Garrosa, E.; Rainho, C.; Moreno-Jimenez, B.; Monteiro, M.J. (2010) The relationship between job stressors, hardy personality, coping resources and burnout in a sample of nurses: A correlational study at two time points. Int. J. Nurs. Stud. 2010, $47,205-215$.

[6] McVicar, A. (2003). Workplace stress in nursing: A literature review. Journal of Advance Nursing, 44, 633-642.

[7] Minter, S. G. (1999). Too much stress? Occupational Hazards, 61 (5), 49-52

[8] Pillay, R. (2009). Work satisfaction of professional nurses in South Africa. A comparative analysis of the public and private sectors. Hum. Resour. Health 2009(7). doi:10.1186/1478-4491-7-15.

[9] Polit D.F. \& Beck C.T. (2010) Essentials of Nursing Research: Appraising Evidence for Nursing Practice, 7th ed. Wolters Kluwer Health / Lippincott Williams\& Wilkins, Philadelphia.

[10] Salilih, S. Z., \& Abajobir, A. A. (2014). Workrelated stress and associated factors among nurses working in public hospitals of addisababa, ethiopia: A cross-sectional study. Workplace Health \& Safety, 62(8), 326-32. doi:http://dx.doi. org/10.3928/21650799-20140708-02

[11] Schuler, R. (1982). An integrative transactional process model of stress in organisations. Journel of Occupational Behaviour , 5: 5-19. 
Work Related Stress among Staff Nurses at a Private Hospital in Singapore

\begin{tabular}{|c|c|c|c|c|c|}
\hline \multicolumn{6}{|c|}{ Appendix: ISMA questionnaire } \\
\hline & & Yes & $\%$ & No & $\%$ \\
\hline 1 & I frequently bring work at night & 42 & 70 & 18 & 30 \\
\hline 2 & Not enough hours at work to do all the things that I must do & 50 & 83.3 & 10 & 16.7 \\
\hline 3 & I deny or ignore problems at work due to my busyness & 40 & 66.7 & 20 & 33.3 \\
\hline 4 & I do the jobs myself to ensure they are done properly & 35 & 58.3 & 25 & 41.7 \\
\hline 5 & I underestimate how long it takes to do things at work & 46 & 76.7 & 16 & 23.3 \\
\hline 6 & I feel that there are too many deadlines in my work & 32 & 53.3 & 28 & 46.7 \\
\hline 7 & I am clear what is expected of me at work though it gives me stress & 35 & 58.3 & 25 & 41.7 \\
\hline 8 & I frequently have guilty feelings if I relax and do nothing & 28 & 46.7 & 32 & 53.3 \\
\hline 9 & $\begin{array}{l}\text { I find myself thinking about problems at work even when I am supposed to } \\
\text { be relaxing }\end{array}$ & 32 & 53.3 & 28 & 46.7 \\
\hline 10 & I feel fatigued or tired even when I wake up after an adequate sleep & 38 & 63.3 & 22 & 36.7 \\
\hline 11 & I often finish other people's work & 24 & 40.0 & 36 & 60.0 \\
\hline 12 & I have unachievable deadlines & 34 & 56.7 & 26 & 43.3 \\
\hline 13 & $\begin{array}{l}\text { My appetite has changed, have either a desire to binge or have a loss of ap- } \\
\text { petite / may skip meals }\end{array}$ & 16 & 26.7 & 44 & 73.3 \\
\hline 14 & I feel irritated or angry I become very frustrated at having to wait & 38 & 63.3 & 22 & 36.7 \\
\hline 15 & If something or someone really annoys me I will bottle up my feelings & 42 & 70.0 & 18 & 30.0 \\
\hline 16 & Different groups at work demand things from me that are hard to combine & 32 & 53.3 & 28 & 46.7 \\
\hline 17 & $\begin{array}{l}\text { I experience mood swings, difficulty making decisions, concentration and } \\
\text { memory is impaired }\end{array}$ & 22 & 63.3 & 38 & 36.7 \\
\hline 18 & I find fault and criticize others rather than praising, even if it is deserved & 32 & 53.3 & 28 & 46.7 \\
\hline 19 & I seem to be listening even though I am preoccupied with my own thoughts & 38 & 63.3 & 22 & 36.7 \\
\hline 20 & My sex drive is lower, I can experience changes to menstrual cycle & 41 & 68.3 & 19 & 31.7 \\
\hline 21 & I find myself grinding my teeth when working & 12 & 20.0 & 48 & 80.0 \\
\hline 22 & $\begin{array}{l}\text { Increase in muscular aches and pains especially in the neck, head, lower } \\
\text { back, shoulders }\end{array}$ & 40 & 66.7 & 20 & 33.3 \\
\hline 23 & $\begin{array}{l}\text { I am unable to perform tasks as well as I used to, my judgment is clouded or } \\
\text { not as good as it was }\end{array}$ & 32 & 53.3 & 28 & 46.7 \\
\hline 24 & $\begin{array}{l}\text { I find I have a greater dependency on alcohol, caffeine, nicotine or medicines } \\
\text { to keep me going }\end{array}$ & 8 & 13.3 & 52 & 86.7 \\
\hline \multirow[t]{2}{*}{25} & I find that I don't have time for many interests / hobbies outside of work & 45 & 75.0 & 15 & 25.0 \\
\hline & Overall: do you experience work related stress? & 33 & 55 & 27 & 45 \\
\hline
\end{tabular}

Citation: Nancy Justine, Fenny Justine, Esther Declara Gani, Geraldine Stephen, Kasmah Yamin, Beatrice Hailis Sebastian, Tukimin Sansuito, Regidor-111 Dioso. Work Related Stress among Staff Nurses at a Private Hospital in Singapore. Archives of Emergency Medicine and Intensive Care. 2018; 1(1): 29-33.

Copyright: (C) 2018 Nancy Justine, Fenny Justine, Esther Declara Gani, Geraldine Stephen, Kasmah Yamin, Beatrice Hailis Sebastian, Tukimin Sansuito, Regidor-111 Dioso. This is an open access article distributed under the Creative Commons Attribution License, which permits unrestricted use, distribution, and reproduction in any medium, provided the original work is properly cited. 